This is the version of the article accepted for publication in African Affairs published by Oxford University Press: https://doi.org/10.1093/afraf/ady019

Accepted version downloaded from SOAS Research Online: http://eprints.soas.ac.uk/25970

\title{
POWER, PACTS AND POLITICAL SETTLEMENTS: A REPLY TO TIM KELSALL
}

\author{
MUSHTAQ KHAN \\ in African Affairs virtual issue doi: 10.1093/afraf/ady019 \\ forthcoming in paper journal October 2018.
}

\begin{abstract}
Tim Kelsall raises important questions about the meaning of political settlements and methods of analysis ${ }^{1}$. I entirely agree with Kelsall on many issues, but I also think there are gaps in the analysis he puts forward, which I address in this response. He argues that to be consistent with everyday meaning, as well as to ensure analytical usefulness, a political settlement has to be defined as an 'agreement among powerful social groups that ends a conflict and sustains a set of institutions and a distribution of power that delivers an acceptable distribution of benefits' (presumably for the powerful social groups in question). This means that for a political settlement to exist there have to be agreements to end conflicts; that these agreements have to be sustainable for some time, (he suggests at least five years); and the agreements have to include an understanding among the powerful that critical institutions have to be protected to prevent an outbreak of conflict. Institutions that are not relevant for the distribution of benefits to the powerful and therefore outside the conflict-ending agreement are not part of the political settlement according to this definition and should be studied at a lower level. I am sympathetic to Kelsall's objectives because we both want to capture what is 'settled' about a settlement, but to my mind his approach faces significant empirical as well as analytical problems.
\end{abstract}

I define political settlements as social orders characterized by distributions of organizational power that together with specific formal and informal institutions effectively achieve at least the minimum requirements of political and economic sustainability for that society. To elucidate the differences between these two approaches, I will describe Kelsall's view of a political settlement as a 'planned order', where critical institutions preventing conflict are consciously agreed upon by powerful groups as a way of distributing rents amongst themselves, and then collectively enforced. In contrast, I describe my view of a political settlement as an 'interactive order' where an identifiable and fairly robust social order exists, but it is the outcome of many interactions between groups and not based on any agreement or pact that can be identified ex ante. The difference is important because the representation of political settlements as consciously planned institutional arrangements does not address some of the most profound questions at the heart of institutional analysis, namely what makes any institutions or agreements enforceable, or the commitments to adhere to them

\footnotetext{
${ }^{1}$ Tim Kelsall, 'Response to Khan', African Affairs Virtual Issue: Political Settlements Research in Africa (2018).
} 
credible? These questions are at the heart of discussions within modern institutional economics and political economy. ${ }^{2}$ Fundamental questions of free riding, distributive conflicts over rents and the credibility of commitments cannot be assumed away by asserting that a group of powerful interests have agreed to enforce a set of institutions. My approach offers an answer, and also helps us address the related question of great policy significance: why do similar agreements and institutions operate differently across contexts? ${ }^{3}$ Without compelling analytical answers to these types of questions, an approach to social orders is not credible.

Kelsall's 'planned order' provides answers to these questions but they are not satisfactory. He argues that there are groups that have the power to disrupt a political settlement distinct from those who do not; that the groups who have disruptive power can only achieve peace if they can reach an agreement among themselves (which could include repressing some groups); and that when they reach an agreement on an allocation of rents that resolves the conflict they will protect this allocation with robust institutions. This is the political settlement. Since the powerful have agreed to enforce these critical institutions, the argument is they will now be enforced, and the powerful will play within these rules. This defines away the fundamental questions in the literature about how groups may free ride on agreements they have made, engage in distributive conflicts, the difficulty of making credible commitments without external enforcement, how informal modifications of institutions happen, and how social orders evolve through changes in important institutions, which they continuously do. In the language of game theory, the social order problem is essentially a problem of a noncooperative game, where we have to explain how order emerges without external enforcement of agreements, but Kelsall's solution implicitly assumes we are in a cooperative game where the problem is to reach agreements between groups because it can be assumed that agreements will subsequently be enforceable.

My approach to political settlements does not take this for granted. Instead, it sees a social order as an outcome of interactions between a large number of groups where the outcomes are various degrees of enforcement of formal institutions, informal modifications of many of these, and different levels of adherence and support for various informal institutions. If these interactions achieve the minimum political and economic reproduction conditions of a society, we have a reproducible social order. This approach gets to the core components of a complex story of structure and agency, and the definition focuses our attention on these components. Depending on the distribution of power and capabilities across organizations, these interactions collectively add up to outcomes that have certain patterns. We can summarize these outcomes in a rate of growth, a Gini coefficient, in measures of overall levels of conflict

\footnotetext{
${ }^{2}$ Robert H. Bates, Prosperity and violence: The political economy of development (W.W. Norton, New York, 2001); Avner Greif, 'Commitment, coercion and markets: The nature and dynamics of institutions supporting exchange', in Claude Ménard and Mary M. Shirley (eds), Handbook of new institutional economics (Springer, Dordrecht, 2005), pp. 727-86; Avner Greif, Institutions and the path to the modern economy (Cambridge University Press, Cambridge, 2006); Douglass C. North, John J. Wallis, and Barry R. Weingast, Violence and social orders: A conceptual framework for interpreting recorded human history (Cambridge University Press, Cambridge, 2009); Charles Tilly, Coercion, capital, and European states, AD 990-1990 (Basil Blackwell, Oxford, 1990).

${ }^{3}$ Mushtaq Husain Khan, Political settlements and the governance of growth-enhancing institutions, <http://eprints.soas.ac.uk/9968>, Research Paper Series on Governance for Growth (SOAS, University of London, London, 2010); Mushtaq Husain Khan, 'Introduction: Political settlements and the analysis of institutions', African Affairs Virtual Issue: Political Settlements Research in Africa (2017), pp. 1-20.
} 
and violence, and so on. These outcomes are the results of many interactive decisions, they are not directly the outcome of agreements between groups, powerful or otherwise to achieve specific outcomes.

Regardless of agreements or intentions, a political settlement is only sustainable when these collective interactions achieve a minimum set of economic and political outcomes that are relevant for that context. The conditions of sustainability are not the same across orders. Empirically, we know that some orders survive with levels of violence that would probably have resulted in new mobilizations that would change the configuration of power, and therefore characteristics of the political settlement, in other contexts. We certainly cannot assume that powerful groups get together to consciously set up institutions to distribute rents in ways that successfully control violence. This would be analytically implausible, and in any case the collective action required for reaching such agreements within and across large groups would be beyond herculean.

Kelsall refers to an important example of a political settlement that he believes supports his interpretation: the Settlement that marked the emergence of a new social order in Britain after the Glorious Revolution of 1688. I agree with him that this is a historically important example of a settlement, and one from which the term political settlement is arguably derived. It is useful to look in some detail at this example because when we apply political settlements analysis to contemporary African and Asian countries, we need to make sure that we are not expecting political settlements to be fundamentally different in contemporary contexts. I argue that the historical evidence shows that this paradigmatic settlement was not based on an 'agreement' to end violence and did not actually have characteristics that would fit Kelsall's definition. Rather, it can be usefully examined and understood in terms of my approach.

The article is organized as follows. In section one, I discuss the relationship between analytical definitions and the everyday understanding of social science concepts, including political settlements. In section two, I discuss the paradigmatic case of the political settlement that emerged out of the Glorious Revolution of 1688 and its implications for an analysis of political settlements. In section three, I discuss the meaning of agency in an analysis of structure. Kelsall argues that structure has to be explained by agency: the agreements of powerful groups keep core institutions defining structure in place. I argue that the analytical narrative behind this does not work at a number of interdependent levels. Agency does indeed affect structure (and vice versa), but agency affects structure through the interactions of many organizations that have to be largely self-sustaining. The difference is vitally important to understand for an empirically and analytically robust approach to political settlements.

Finally, in section four, I look at two immediate implications of these distinctions. I argue that my approach helps us to avoid two types of errors that could follow from a definition of a political settlement as a conflict-ending agreement between elites. A 'pacts' approach to political settlements could suggest that if powerful groups could be made to agree, they could end a conflict and achieve a political settlement. It could also suggest that once such an agreement has been achieved, we should be very careful not to upset it as it could unleash conflict. Both conclusions are at best misleading, at worst very problematic. Political settlements are not the outcome of agency in this simple sense, and it can be dangerous to suggest that they are. They are indeed the outcome of the interaction of many, possibly thousands of organizations and their decisions, but 
this interactive outcome of agency is an entirely different matter from an agreement between elites. Moreover, particular political settlements can have many negative features and attempting to address these, sometimes even by questioning fundamental rent-allocating institutions, will not necessarily trigger violence. This is too conservative a position. Political settlements are always evolving and incremental changes can add up to significant variations over time. We are entitled to assess the economic and political outcomes of a particular political settlement and to provide policy advice that can try and nudge its evolution in particular ways. If agreements between elites were really so robust, every change in a political settlement would require a new agreement or it would trigger violence.

\section{Definitions and everyday discourse}

I entirely agree with Tim Kelsall that when we use everyday words like markets, states, and politics, we should try to keep close to their everyday meaning. But we should also aim to identify the most important characteristics of what is being described so that new analytical insights can be derived. For instance, people talking about markets usually refer to a place where they go to buy things. But while there are competing analytical definitions of markets, none of them focus on markets as places. That is because the market as a place detracts from more essential characteristics of markets, which a good definition can help to identify and focus on, for instance, by helping to identify the conditions for efficient allocative outcomes. Markets have therefore been defined, for instance, as institutions enabling transactions based on voluntary contracts with freedom of entry and exit. It is true that such a definition risks losing some of our everyday audience, who may never have thought of markets as a set of rules. But we gain insights that illuminate why we are interested in markets in the first place, as better ways of allocating resources than some other alternatives. This particular definition enables us to see that all markets may not be places, and that some places claiming to be markets may be so coercive that perhaps we should not call them markets at all. It also means that there may be more than one way of usefully defining a market, depending on the questions we are asking.

In the same way, my definition of political settlements does indeed look at historical and everyday references to political settlements. A political settlement is indeed a 'settled' social order, and it is settled because its 'politics' achieves sustainability. Political settlements understood in this way are important because social orders describe the institutional and organizational structure of a society in which agency has to be located for policy analysis. This has implications for the operation of institutions and policies and the feasibility of different types of institutional and policy changes. My definition of a political settlement provides a definition that is useful for addressing a broad range of analytical questions of this type. There may, of course, be other ways of defining a political settlement to answer somewhat different questions. However, the way in which Kelsall elaborates his 'agreement-based' or 'planned order' definition of a political settlement does not work in my opinion, because it violates a number of analytical and empirical observations. It is important to interrogate historical examples to see what was essential in these orders, and therefore what must be included in a general definition and what should be excluded. 
While the popular usage of the term does indeed often refer to post-conflict agreements as marking the emergence of an order, many post-conflict agreements break down and many social orders exist and evolve without any identifiable conflict-mitigating agreements. So a general definition of a political settlement should certainly be able to cover successful post-conflict agreements as a special case but should also be able to do much more. Moreover, once we define sustainability in an analytical way, with reference to historical evidence, it becomes clear that sustainable social orders do not require a total absence of violence (indeed many orders survive with high levels of conflict). Finally, the empirical evidence also tells us that the (degree of) enforceability of institutions varies greatly across political settlements, so clearly agreements to enforce critical institutions, even if they could be found, are not equally credible across different contexts.

The level of conflict is not a useful marker for the existence of a reproducible social order because the sustainable level of violence appears to depend on how individuals and groups respond to violence. A continuously escalating level of violence is unlikely to be sustainable because the economy is likely to shrink at an accelerating pace, and new mobilizations are likely to emerge in response to deteriorating economic and political conditions. But human societies appear capable of adjusting to moderate to high levels of violence provided these levels are relatively stable and individuals and groups can carry on a wide range of activities that allow the system to reproduce over long periods. Nigeria, South Africa, Pakistan or India (just to pick a few important countries at random) have had varying levels of internal conflict, including highintensity conflicts and violence over long periods. It makes no sense to say these societies do not have political settlements because many institutional characteristics of these societies are relatively stable, the societies reproduce, and changes are usually incremental and evolutionary.

There are moments in the history of these countries, like the Biafra conflict of 1967-70 or the conflict in East Pakistan in 1971 when violence rapidly escalated and the local political settlement could certainly be said to have broken down, but these are relatively short-lived episodes. In general, the requirement of a zero or an arbitrarily low level of conflict or violence cannot serve as a useful criteria for defining the presence or absence of a political settlement. Moreover, the degree of fragility of a political settlement may not correspond to the level of ongoing conflict in a simple way. Many social orders which suppress discontent and appear to be without conflict can suddenly prove to be fragile, like Syria in 2011. Think also of how the Arab Spring was triggered when a solitary street vendor called Mohamed Bouazizi set himself on fire in 2010 in Tunisia when authorities confiscated his goods. Tunisia was a relatively stable and high-growth economy before that point, but the rapid escalation of violence and disorder shows that the previous political settlement was quite fragile. Our analytics should be able to say something about the fragility or robustness of political settlements, but we cannot read that off from recent levels of violent conflict. For both politics and the economy, sustainability therefore has to be carefully understood in terms of the threats to the reproducibility of the system.

The end of a conflict can mark a change in the distribution of organizational power, and a post-conflict settlement can therefore be a useful marker of a discontinuous break in the evolution of power in a society. But social orders can also evolve or change in other ways. For instance, today's British political settlement has evolved through many 
incremental and discontinuous changes since the 1688 Revolution but without many post-conflict declarations. The contemporary British settlement is clearly very different from 1688 but how should we identify its characteristics if we are looking for conflictending declarations? Long periods of incremental change can be just as significant as bursts of discontinuous change. Focusing only on post-conflict agreements limits, in my opinion, the usefulness of the political settlements framework. Other types of events can be just as useful as markers for locating points when changes that have been gradually happening are judged to be of substantial importance. Dating these points can be a matter of debate, but clearly many other markers apart from conflict-ending agreements can be useful. For instance, gradual changes in technologies and markets can lead to the decline of old industries and the rise of new ones, the growth in employment of new groups, like women, or the unemployment of previously employed groups, like coalminers. These changes more or less gradually change the distribution of power across organizations and can result in significant changes in the distribution of organizational power. We can mark these gradual changes with discrete events that bring them to public notice, like the collapse of a trade union movement, or the Brexit vote of 2016, as long as we remember that the changes that they record developed incrementally. A post-conflict agreement or constitution is just a marker, no different from an unexpected election result or the defeat of a once-powerful union in a strike, on the basis of which we may hypothesize significant changes in the underlying distribution of power and the emergence of new coalitions.

These inflexion points in evolutionary paths are initially a matter of judgement in the first instance, and sometimes the distribution of organizational power may also change without clear markers. But observations over time of a variety of evidence on organizational power and institutional operation can help determine whether a hypothesis of changes in the distribution of power can be verified, whether they are holding up over time, evolving in particular directions, or being reversed. The more stable and reinforcing a distribution of power becomes, the more our analysis of a political settlement should take it into account. The effects of a ruling coalition introducing particular policies or institutions, including constitutional settlements, depend on how the universe of organizations, including apparently not-so-powerful ones, respond to these changes. This is why many post-conflict constitutional agreements fail to achieve their intended effects, as do many 'normal' institutions and policies. Agreements, like institutions, even when ratified as constitutions, are simply declarations of intended formal institutional arrangements. These may or may not be implementable in practice. The task of analysis is to identify the conditions that make a settlement sustainable both in an immediate sense and over time. A document or agreement prepared by a few leaders of ostensibly powerful organizations may mark a significant shift in the distribution of power, but it may also be a trivial exercise that history will not remember.

My definition of a settlement may appear to be somewhat different from the everyday understanding because I want to identify general characteristics of political settlements that can also help us understand why 'agreements' to support particular institutions hold up in the subset of settlements where agreements appear to be important. This approach does not avoid critical questions about the credibility of commitments and the enforceability of formal institutions. The important insight is that the enforcement of particular institutions depends on the distribution of organizational power across different types of organizations affected by that institution. If a group of powerful 
leaders were really powerful enough to set up institutions to protect their rents, it would be hard to explain why they would not also agree to modernize the economy and multiply many times over the rents they get. The power of powerful organizations in developing countries may be much less than Kelsall assumes, a point I come back to later. $^{4}$

In general, the claim that some institutions are simply going to be enforced because some powerful groups have decided that they should be is not analytically credible. Who are these powerful groups, how do we know they really have agreed, or that they have the power to enforce, or (most importantly) that their inter-group and internal agreements will not break down? Powerful groups are no different from other groups, they may try to free ride on agreements and they may disagree about the distribution of rents, so an agreement to protect a set of permanent institutions cannot be selfsustaining in the general case. I will elaborate these points with reference to the settlement that emerged after the Glorious Revolution. If an agreement among the powerful to end conflict did not exist even in this paradigmatic case of a settlement, the relevance of a definition based on conflict-ending agreements becomes very questionable.

Finally, for me the evolutionary dynamics of a settlement is the most important feature determining its long-term sustainability. This describes the direction of the institutional and organizational changes that are likely to be allowed by the configuration of organizational power and capabilities. Of course, 'allowed' does not mean necessitated. There is nothing deterministic about political settlements, and agency plays a big role in determining the actual directions of travel. The key point is that a dynamically sustainable settlement is one that can evolve incrementally without too many serious discontinuous disruptions, and which can maintain or improve levels of economic and political performance. As they evolve, the distribution of organizational power within political settlements inevitably changes, but in the general case this does not lead to huge outbreaks of violence. In the general case, important incremental institutional changes are always happening, and many of these do not need renegotiations of agreements protecting the rents of the powerful. This is an unnecessary and empirically incorrect assumption to make in the definition of a political settlement.

The evolutionary path of political settlements depends on the strategies of cooperation, conflict, production and rent seeking of a variety of organizations. What matters is the relative power of these organizations because this is a critical factor determining their strategies and their outcomes. Their relative power in turn depends on 'structure', the configuration of organizational power at a macro-level, which helps us understand how a particular organization at a micro-level can relate in collaborative or conflictual ways with others. On the other hand, the collective 'agency' of organizations affects economic and political outcomes, and over time can change the structure, the configuration of power at the macro-level. These macro-level changes in structure are not negotiated as agreements between powerful groups. Rather, they are outcomes as agency interacts with structure in a relatively decentralized way. This is an important difference between our two approaches and one that will be elaborated later. As

\footnotetext{
${ }^{4}$ We frequently see this in post-conflict negotiations, see for instance, Pallavi Roy and Mushtaq Husain Khan, Nepal's political settlement and inclusive growth: Not quite business as usual, SOAS Working Paper (SOAS, London, 2017).
} 
observers, we can judge the implications of an evolving political settlement for delivering desirable development outcomes, like maintaining low levels of violence, reducing poverty, achieving economic inclusion, enhancing political rights and so on. We can also analyse the likely feasibility and effectiveness of particular institutional and policy changes to achieve outcomes in line with our own values, in the form of policy advice to groups whose interests may be aligned with these objectives.

\section{The Glorious Revolution and the interpretation of 'agreements'}

I will illustrate some of these issues with reference to the political settlement that emerged out of the Glorious Revolution of 1688 before discussing the analytical implications in the next section. I agree that 1688 was a paradigmatic case of a political settlement, that it was robust, and that it had significant implications for subsequent development. But I take issue with the claim that this was a conflict-ending agreement that set up institutions to protect the rents of the powerful. An examination of the historical facts suggests that this post hoc interpretation is not supported by the evidence. The factors that made this settlement stable and determined its evolutionary outcomes cannot be read off either from the Bill of Rights of 1689 or the Act of Settlement of 1701, the two 'agreements' that defined the settlement, or any other agreements made at that time. Moreover, these settlement agreements did not even intend to end the most important conflict, that between Catholics and Protestants. The settlement institutions were a small subset of the institutions that determined Britain's economic and political dynamics and the distribution of rents in the subsequent period. What is more, the institutions set up under the Bill and the Act rapidly evolved in subsequent years, suggesting that they were not core institutions allocating rents to prevent conflict, and they were certainly not immutable. The most important feature of the political settlement of 1688 was rather a relatively small shift in the distribution of power that led to a different evolutionary path for Britain, accelerating its capitalist transformation. The characteristics of the organizations that benefited and lost out as a result of this shift in the configuration of power is for me the most significant aspect of that political settlement. This reconfiguring of power had truly massive long-term evolutionary implications and one that our definition helps to capture.

At the heart of the Glorious Revolution was a Dutch invasion of England led by William of Orange to overthrow James II, the Catholic king of England, Scotland and Ireland. The Bill of Rights of 1689 legalized this successful coup, re-established the primacy of the Anglican religion, and established a constitutional monarchy where the king was constrained by parliament. Further restrictions on the rights of the new monarch, William, were introduced in the Act of Settlement of 1701 and the constitutional monarchy continued to be reformed in subsequent decades. While we can all agree that there was a significant break in the evolutionary path of the political settlement, the question is what was the significance of the 'agreements' enshrined in the Bill of Rights and the later Act of Settlement or any other agreements that we can find in that period? Are these agreements themselves the 'settlement', did they intend to end conflict and did they actually end the conflict, were they agreed upon by all powerful groups, and did they set out the critical institutions that powerful groups agreed needed to be enforced to protect a set of benefits to prevent a return to conflict? The answer to all of 
these questions is no, or at best, not really ${ }^{5}$. And that is not surprising given the implausibility of enforceable collective agreements between large groups.

The first important observation is that the settlement agreements were not even about ending conflicts. The conflict between Catholics and Protestants continued after 1688. Nothing in the Bill of Rights or the Act of Settlement aimed to end this central conflict with any allocation of rents or agreements with the Catholics. Instead, the Bill of Rights and the Act of Settlement articulated an intention to enforce with greater vigour already existing institutions that had led to some of the conflicts, namely restrictions on the rights of Catholics and constitutional principles that limited the power of the monarch. The enforcement of these institutions had simply become more feasible as a result of a shift in the distribution of power and a reconfiguration of coalitions that evolved as a result of a foreign invasion. The institutions themselves were not new. As long ago as 1215, the Magna Carta, an earlier 'agreement' between a king and his barons, had asserted the principle that kings should only rule with the consent of the taxpaying barons. But that agreement had been immediately annulled and was never effectively implemented. The constitutional monarchy at the heart of the 1688 settlement revived this institution and its enforcement was attempted once again on the basis of a new configuration of power. Similarly, the supremacy of the Anglican religion had been established more than a century earlier by Henry VIII as part of his state-building strategy. The re-establishment of Anglicanism and the exclusion of Catholics from public life, the second plank of the settlement, was also clearly the revival of an earlier institution. These institutions had been repeatedly overturned and fought over because the balance of power between shifting coalitions had not supported their effective implementation.

However, the structure of the economy and society had changed gradually over time. The complex coalition of interests demanding a constitutional monarchy had grown stronger, as had those who wanted to construct a nation-state independent of continental Catholic powers. The Dutch invasion provided the small but critical tilt in the balance of power in favour of the diverse coalition who wanted these institutions, allowing them to suppress those who were opposed to them. As many powerful groups including Catholics, the King and his followers, and aristocratic landed interests had resisted these institutions in the past, the immediate result of the invasion was an increase in conflict over subsequent years until the older forces were militarily defeated, initially with the help of the Dutch forces. Many powerful groups did not 'agree' at all with the Dutch invasion, the expulsion of the legitimate king, or the exclusionary institutions reinforced after 1688. Violence by Catholics to restore James continued, particularly in Ireland for many years. Memories of William's bloody victory in the Battle of the Boyne in 1690 can still evoke passion and violence in Northern Ireland. The gradual achievement of peace after 1688 can only be described as the reaching of an agreement amongst the powerful by doing quite a lot of violence to the word.

Secondly, not only were powerful defeated interests not part of the agreement, the winning side was also deeply divided. It is not even possible to say there was an agreement among them. The conflicts ostensibly about religion and the rights of the

\footnotetext{
${ }^{5}$ Geoffrey Holmes (ed.) Britain after the Glorious Revolution 1689-1714, (Macmillan, London, 1969); Scott Sowerby, Making toleration: The Repealers and the Glorious Revolution (Harvard University Press, Cambridge, Mass., 2013); Tilly, Coercion, capital, and European states, AD 990-1990.
} 
monarchy were banners under which complex coalitions had formed with conflicting and overlapping interests. Beliefs, ideologies and personal ambitions all played a role, but there were also identifiable economic and political interests. Since the sixteenth century, there was a growing capitalist transformation in agriculture, leading to conflicts between aristocratic landed interests and emerging capitalist ones. The Enclosures were converting common village land into private land to create capitalist sheep farms but they also undermined peasant agriculture and created an agrarian proletariat. The monarchical state initially resisted the Enclosures, partly because of public order threats, but also to prevent enclosing landlords becoming too powerful. These processes had driven agrarian conflicts that occasionally contributed to escalations of violence as in the Civil War of the 1640s. ${ }^{6}$ By 1688 there were many capitalist landlords who wanted constitutional restrictions on the monarchy and greater powers for parliament. They saw this as a way of guaranteeing their property rights from monarchical encroachments and developing further institutions to promote their interests. Capitalist interests in commerce and industry were even more in favour of a constitutional monarchy, to make the executive more accountable in its spending and to ensure that policies reflected the interests of modern sectors. On the other hand, aristocratic interests wanted a stronger monarch as a way of protecting hereditary rights. As a result, though many of them were anti-Catholic, they opposed the Bill of Rights in the House of Lords and only partially conceded at the very end. The military intervention had cornered them and forced them to make strategic choices. They decided that protecting the powers of the monarch could lead to a Catholic revival and would also involve taking a position against William's forces.

A very important part of the story is the fact that 'landed' and 'moneyed' interests were not corporate groups that had solved their own internal collective action problems to take a collective position on rents or institutions. In reality, they were complex coalitions whose individual components could change their positions relatively easily. These conflicting interests temporarily came together in 1688 to support the Bill of Rights in a short-lived alignment of interests that was based on many strategic and opportunistic calculations, undoubtedly influenced by the presence of a Dutch army. That this was a compromise that no side expected to last for long is demonstrated by the intense conflicts between conservative landed interests and the newly emerging capitalists after 1688 , often coming close to violence. ${ }^{7}$ The Whigs representing the emerging capitalist and trading interests proceeded to further limit the powers of the monarchy, re-interpreting and contravening the spirit of the agreements they had recently made with landed interests. ${ }^{8}$

As the balance of power continued to shift, aristocratic interests could not resist a series of changes that went against them. This was the beginning of decades of conflicts between Whigs and Tories with the tide gradually shifting in favour of the former and the emerging capitalist interests that they broadly represented. It is not plausible to argue that there was an enforceable agreement within the winning groups about the

${ }^{6}$ Ellen Meiksins Wood, The origins of capitalism: A longer view (Verso, London, 2002) p. 109; Robert L. Heilbroner, The worldly philosophers: The lives, times, and ideas of the great economic thinkers (Simon and Schuster, New York NY, 1999), chapter two.

7 William Arthur Speck, 'Conflict in society', in Geoffrey Holmes (ed.) Britain after the Glorious Revolution 1689-1714 (Macmillan, London, 1969), pp. 135-54.

8 Jennifer Carter, 'The revolution and the constitution', in Geoffrey Holmes (ed.) Britain after the Glorious Revolution 1689-1714 (Macmillan, London, 1969), pp. 39-58. 
institutions that would regulate their rents. Wars with the French also continued and intensified, and these too had significance for internal politics as a defeat could have allowed the return of James. Given the internal conflicts and external wars, the 'settlement' could hardly have appeared to contemporaries as a decisive end of conflict or a robust agreement amongst all powerful groups about critical institutions necessary to end the conflict.

So how should we understand this settlement to be consistent with these observations? The mosaic of interests across many different types of organizations meant that coalitions could be constructed in different ways. The problem was not that the powerful organizations who were fighting had to reach an agreement in order to stop the fighting. Rather, the problem was to construct coalitions of the powerful and notso-powerful that were sufficiently powerful to rule. How this coalition was put together had deep consequences for the operation of institutions at all levels of society. William's invasion with around 15,000 mercenaries was sufficient to tilt the balance in favour of groups linked to emerging capitalist interests and the modernization of the state. It also forced strategic realignments by some aristocratic landed interests to support the winning coalition because successful resistance to a constitutional monarchy now looked less feasible. This produced the coalition that signed the Bill of Rights. But this signing did not mean that they reached collective agreements about rents and institutions. It was not as if different types of landlords, Anglican interests, commerce and industry each had identifiable groups, that these groups wanted rents, and that they sat together to agree on institutions that gave each of them an agreed share of rents. Rather, quite a disparate group of organizations came together in a coalition to create institutions whose rents remained disputed amongst themselves. The coalition was simply the best option for them at the time, but it was clear that many of the groups within the winning group would continue to try to renegotiate a better deal. This political settlement, therefore, has to be understood as a new configuration of power that allowed the emergence and enforcement of a particular set of institutions. What made this political settlement noteworthy were its dynamic characteristics.

This takes me to my third point. Historians have convincingly argued that the critical institutions that defined the dynamics of British society in the eighteenth century cannot be read off from the Bill of Rights or the Act of Settlement. ${ }^{9}$ The evolution of critical economic institutions like the rules underpinning the Bank of England, the gradual modernization of the state and its finances, or the organization of the party system were arguably much more important for allocating rents in ways that ensured economic and political stability. These institutions emerged in the decades after the settlement and radically changed the allocation of rents, disadvantaging landed interests, one of the groups supporting the 1688 settlement. Far from powerful groups collectively protecting institutions, important institutional innovations were driven by ongoing internal and international conflicts. ${ }^{10}$ Wars created the demand for more money to finance them and taxation increased as a result, but with parliamentary accountability so did the military effectiveness of the state. Limiting the power of the monarch and the aristocracy expanded the policy space for private enterprise. This not only helped the domestic capitalist sector but also allowed private organizations like the East India

\footnotetext{
${ }^{9}$ Geoffrey Holmes, 'Introduction: Post-revolution Britain and the historian', in Geoffrey Holmes (ed.) Britain after the Glorious Revolution 1689-1714 (Macmillan, London, 1969), pp. 1-38.

10 Tilly, Coercion, capital, and European states, AD 990-1990.
} 
Company to operate more freely, changing the global distribution of power in the next half century. The most significant aspect of the 1688 settlement was that it allowed a different co-evolution of institutions and organizations that benefited the expansion of British capitalism. These institutions radically changed the distribution of rents, and also Britain's position in the world.

The immediate characteristic of the Revolution settlement, far from the construction of mutually agreed institutions to share rents, was the better enforcement of a number of already existing but divisive institutions. But the unintended longer-term consequence of these exclusionary institutions was to empower a number of groups who had significant productive potential to use these opportunities to further enhance their own productivity and the modernization of the state. Therefore, the much more important aspect of 1688 was the dynamic characteristics of the new political settlement and the way it enabled incremental changes in institutions and organizations over the subsequent decades. It did not fix critical institutions, rather the reverse. The settlement, seen as a new configuration of power, allowed institutional changes in ways that reinforced an accelerating capitalist transformation, allowing deeper economic and political stability over time, albeit with ongoing conflicts.

This focus on power, capabilities and evolution in seventeenth century England can help us to understand better why the Dutch intervention in England was so different in terms of long-term implications compared to US, French and other interventions in Afghanistan, Mali or the Central African Republic in recent years. Like the Dutch intervention in England, these external interventions did help local coalitions win or retain power and helped sustain some institutions that winners claimed were important for ending 'the conflict'. However, in these recent examples, the tilt in the balance of power did not trigger similar dynamic developments because of differences in the capabilities and power of domestic organizations. The distribution of power did not become 'indigenized' in sustainable capabilities of domestic organizations. This is because unlike seventeenth century England, the winning coalitions in say Afghanistan were not linked to capitalist forces of agrarian transformation who could use the small boost in their holding power to drive further institutional changes to enhance their productivity and competitiveness. The political settlement of 1688 was significant because of this evolutionary dynamic - not the rigidity of its institutions. Without that dynamic, the military victory of a coalition remains just that. Reproducible social orders of some variety do emerge, but they may require lasting external interventions to sustain them, often with high levels of 'normal' violence. ${ }^{11}$

Our approach can also explain why the much lauded Magna Carta of 1215 actually had a very unimpressive history compared to the lasting effects of the Bill of Rights of 1689. The configuration of power and capabilities changed significantly between these two 'agreements'. Magna Carta was much more directly an agreement to end a conflict between an unpopular king and his barons, but it failed miserably when it came to be

11 Christine Bell and Jan Pospisil, 'Navigating inclusion in transitions from conflict: The formalised political unsettlement', Journal of International Development 29, 5 (2017), pp. 576-93 describes social orders that require permanent external support as a 'formalized political unsettlement'. Despite the difference in terminology, they recognize these are sustainable social orders when international organizational support is accounted for. Clearly, Afghanistan's social order is fragile and can easily tip into escalating levels of violence, particularly if foreign forces begin to withdraw, but the social order has lasted for far longer than the five year test set by Kelsall despite high levels of conflict. 
implemented. This is because Magna Carta was signed at a time when the power of productive groups was not distributed widely enough for checks and balances on the monarch to be effective. It was annulled shortly afterwards, and then repeatedly revived and shelved in the centuries that followed.

\section{Agency, power and rents}

The discussion of 1688 is relevant for refining our understanding of political settlements for contemporary applications in Africa and elsewhere. Kelsall's definition of a political settlement is derived from a particular reading of events like those of 1688 to develop an analytical narrative to describe how the social order came about. This analytical narrative is flawed and therefore Kelsall's definition of political settlements is misleading. The narrative begins with a binary distinction between groups that are powerful enough to disrupt a social order and those that are not. A second binary claim is that all the groups who are powerful have to reach a collective agreement to end conflict by creating institutions that share rents, otherwise we will have conflict or a stalemate. The logic is that if a social order exists, an agreement between all powerful groups must have emerged because if any powerful group was left out of the agreement, they would disrupt the order (unless they are repressed). The third binary distinction is that powerful groups can then either work within the institutions they have created (and which they agree are necessary for keeping the peace), or they can try to change these institutions (leading to conflict). As the core institutions were constructed to create just the right distribution of rents across powerful groups, Kelsall concludes that the latter will not attempt to change these institutions because this will result in violence. Kelsall then distinguishes between real 'political settlements' where core institutions are stable because they are based on these types of agreements and 'stalemates' which are reproducible social orders but not based on agreements. Social orders may reproduce without agreements but he argues that these orders can be rapidly overturned and are therefore described as stalemates. This appears to be a plausible line of argument, but each of the binary distinctions on which it depends is unsustainable.

Kelsall's first claim is that we can distinguish between groups that have the power to 'overturn' or seriously disrupt a settlement from those that do not have such a power. If we can identify the organizations that are powerful in this sense, all of them have to agree on a distribution of rents or be repressed if conflict is to stop. Without such an agreement, or their repression, powerful organizations demanding a bigger share of rents will disrupt or 'overturn' the social order. Neat as this argument is, the classification of organizations in terms of disruptive power is very misleading. Individual organizations rarely if ever have the power to overthrow or seriously disrupt a political settlement on their own, independently of what other groups are doing. If there were such organizations, it would be incredibly difficult to reach any agreements with them. In reality, a wide range of groups have some disruptive power, but typically no group by itself can 'overturn' or seriously disrupt a social order unless the collective responses of many other groups allow this to happen. This is even true for groups like the army, perhaps one of the few groups that could in theory significantly disrupt a social order on its own, particularly in developing countries, where productive groups

are relatively weak. But even armies realize that their power is limited because without the consent of many other groups, their attempts to extract more rents through 
disruption can induce weaker organizations to construct coalitions that can collectively block them. This is why when military leaders rule in developing countries, they typically do so by linking with a variety of allies to counter-balance existing networks. Many of these allies may themselves not be very powerful, but their collective support is critical. For instance, military governments in countries like Uganda or Pakistan have often sought to check established patron-client networks by constructing new networks involving lower-level groups at the village or provincial level, who in turn thereby become powerful relative to other local level groups.

The power of any individual group thus depends not only on its internal economic, political or military characteristics and its success in solving its collective action problems, but also (and critically) on the networks and coalitions they can form and the responses of other groups. Power is always relational. This is why patron-client networks play such an important role in my analysis of political settlements and the evolution of institutions. ${ }^{12}$ A group that appears not to be powerful, such as a villagelevel political faction, can be powerful in a local context because they are part of a particular patron-client network or coalition involving higher level groups. This is why I think Kelsall is wrong to say that we can clearly limit a political settlements analysis to institutions that deliver rents to powerful organizations and the organizations that have the power to disrupt the social order. We cannot do that with any clarity because we do not have a list of organizations that have disruptive potential. Powerful networks and coalitions have complex ramifications that need to be explored and may involve groups that are not in themselves powerful. In addition, these networks can change and evolve over time. Weak organizations may wield considerable localized power depending on how they are networked. It is therefore important to abandon a binary approach in the analysis of organizational power. Kelsall is aware of this complexity, for instance in the discussion around his Figure 2, but the narrative of agreements of the powerful is not consistent with a nuanced understanding of how power is structured.

Because coalitions can be refashioned, ruling coalitions are not predetermined, nor are their strategies of staying in power. Some powerful groups can be, and often are, excluded from a ruling coalition because the coalitions they can construct are not powerful with respect to other coalitions. When this happens, institutional changes can take place that not only affect their access to rents, but also allow further incremental institutional changes that may make it difficult for them to come back. This is what happened to landed interests or the Catholics in 1688. This is also why the exclusion of powerful organizations often does not require repression. Some powerful organizations may fight back violently (like the Catholics did for a while) but others may not (such as the much more powerful landed interests). Responses depend on perceptions of the responses of others and the chances of organizing new coalitions. Thus, powerful excluded groups may choose not to engage in disruption because of strategic calculations (for instance because they need to build coalitions before they can act), or because of other compulsions (for instance because their survival depends on transactions that would be threatened by disruption), or, as Kelsall recognizes, because

\footnotetext{
12 Mushtaq Husain Khan, 'Patron-client networks and the economic effects of corruption in Asia', European Journal of Development Research 10, 1 (1998), pp. 15-39; Mushtaq Husain Khan, 'Rentseeking as process', in Mushtaq H. Khan and K.S. Jomo (eds), Rents, rent-seeking and economic development: Theory and evidence in Asia (Cambridge University Press, Cambridge, 2000), pp. 70-144; Mushtaq Husain Khan, 'Power, property rights and the issue of land reform: A general case illustrated with reference to Bangladesh', Journal of Agrarian Change 4, 1-2 (2004), pp. 73-106.
} 
of threats of repression. These complex responses are not stalemates. They are the normal operating procedures in any political settlement, and therefore a 'stalemate' according to his definition would be impossible in practice to distinguish from what he calls 'real' political settlements.

Kelsall's second claim is that powerful groups have to reach long-lasting agreements amongst themselves to fix institutions allocating rents. This is implausible for a number of reasons, some implicit in the previous discussion. As the configuration of power is always incrementally evolving, organizations cannot agree to fix the distribution of rents in any credible sense. In my political settlements analysis, the distribution of rents across organizations does tend to get aligned with the configuration of power, but it does so through many different adjustments brought about by horizontal interactions between organizations, changes in production and rent-seeking strategies and so on. This is how agency operates in complex systems without the third party enforcement of contracts. The alignment of rents with the distribution of power cannot plausibly happen by the powerful organizations coming together and agreeing to a distribution of rents by setting up appropriate institutions. Thus, while Kelsall and I both agree that the distribution of rents and the distribution of power are brought into line, we are identifying radically different processes through which this happens.

Kelsall's method of alignment is based on positing that a group of powerful organizations exists, they have the power to enforce institutions, they agree to enforce institutions that achieve a distribution of rents to stop conflict, and this constitutes a political settlement. I have tried to show that almost no step in this narrative is credible. In my analysis, an alignment of power and rents nevertheless tends to happen through horizontal interactions across organizations. Organizations that find themselves in coalitions lacking power are unable to protect their rents, and those who do can mobilize their power to create formal and informal institutions to further reinforce their rents or capture more. This is effectively what was happening in England after the 1688 settlement. In developing countries, where the capitalist sector is even less developed and power is typically organized through patron-client networks, the processes can be more complex. Powerful organizations like some large firms or middle peasants can lose rents if they are in weaker networks, while other large firms or peasants can gain. ${ }^{13}$ If organizational structures and capabilities are such that the winners seek rents in ways that further enhance productivity, create jobs or open up political opportunities, and this was the distinctive feature of many of the winning organizations in England at that time, the networks who are powerful tend to get even more powerful and their rents become more stable. The two approaches to describing how alignment happens are based on very different underlying models of how agency and structure interact.

In my understanding of a political settlement, we need to look at a broader range of organizations to identify configurations of power that can depend on networks involving many lower-level organizations that can be put together in different ways. It would be very misleading to rule out any group as irrelevant for the political settlement. Similarly, in my approach, all institutions are potentially subject to a political settlements analysis for the same reason. Apparently trivial village level institutions for water sharing may be distorted and modified by powerful local-level organizations

\footnotetext{
${ }^{13}$ Khan, 'Power, property rights and the issue of land reform: A general case illustrated with reference to Bangladesh'.
} 
whose relative power vis-à-vis other organizations cannot be understood without locating them within relevant vertical or horizontal networks. Clearly, given the complexity of social organization, we have to be selective in our description and analysis from a practical point of view. We are entitled to use metonymic abbreviations like 'the Catholics decided' or the 'landed interests agreed' as long as we realize these are summaries of complex interactions within and across groups and that the power of these groups depend on their relationships with others. ${ }^{14}$ If Kelsall used 'agreements' in the same metonymic sense, there would be no significant difference with my method. But if he really means that powerful groups sit together and make agreements to allocate rents, I believe that is wrong both in terms of a description of empirical processes as well as being analytically implausible in terms of missing enforcement mechanisms.

Kelsall's final claim follows from his first two. This is that once a conflict-ending agreement emerges, powerful groups will play within these rules, and thus core institutions will be robust. This claim too breaks down if we understand that no such binding agreements exist. Indeed, formal institutions are generally weakly enforced and informal modifications are common in developing countries going through social transformations. ${ }^{15}$ A rent seeking analysis of institutions and institutional change tells us that all societies have a variety of rules that are more or less rigid (formal and informal institutions), and all societies are also continuously contesting these rules through intense rent seeking activities. ${ }^{16}$ Given the huge payoffs of rent seeking, it is implausible to believe that powerful groups will be able to organize collective action to ensure that some set of institutions will be out of bounds for distortion or change through rent seeking for all powerful groups. Challenges to fundamental institutions is normal in all political settlements. Sometimes this can result in conflicts, and this is why conflicts exist in all political settlements. But many rent-seeking activities affecting fundamental rent-creating institutions do not result in conflicts for reasons already discussed, and moreover the relative power of the powerful also changes over time. The difference claimed between elites who are playing within the rules (in a political settlement) and those who are attempting to change the rules (in a stalemate) is therefore analytically not very useful. Kelsall is clearly right in saying that social orders must have many robust institutions. The task of political settlements analysis is to identify what these are and why they are robust, but we can only do that by looking at how institutions emerge out of interactions across organizations given the characteristics of the macro-configuration of power. The mistake is to believe that institutions are robust because a group of elites have decided that they must be.

We can now connect the rent-seeking analysis with that of violence and conflict. Rent seeking is the process through which policies and institutions evolve. In developing

\footnotetext{
${ }^{14}$ I use 'metonymy' in the sense used by Tilly, Coercion, capital, and European states, AD 990-1990 p. 34.

${ }^{15}$ Mushtaq Husain Khan, 'State failure in developing countries and strategies of institutional reform', in Bertil Tungodden, Nicholas Stern, and Ivar Kolstad (eds), Toward pro-poor policies: Aid institutions and globalization (Oxford University Press and World Bank, Oxford, 2004), pp. 165-95; Mushtaq Husain Khan, 'The capitalist transformation', in K.S. Jomo and Erik S. Reinert (eds), Development economics: How schools of economic thought have addressed development (Zed Press and Tulika, London and New Delhi, 2005), pp. 69-80.

${ }^{16}$ Khan, 'Rents, efficiency and growth'; Khan, 'Rent-seeking as process'; Holmes, (ed.) Britain after the Glorious Revolution 1689-1714; Sowerby, Making toleration: The Repealers and the Glorious Revolution; Tilly, Coercion, capital, and European states, AD 990-1990.
} 
countries, formal rules are not well-enforced. Powerful organizations do not support the enforcement of formal rules to the extent that we observe in advanced countries because their business models do not require complex contracting and the enforcement of a rule of law to the same extent. Rent seeking is therefore likely to be associated with rule violations in developing countries and rule-violating rent seeking can easily escalate into violence. This is 'normal' given the characteristics of developing country political settlements, and therefore the presence of conflict or even some violence does not necessarily tell us that the political settlement is breaking down or absent. Political settlements can break down, for instance if many of the institutions necessary for system reproduction collapse. But these are relatively rare events.

Countries like Afghanistan do indeed pose a challenge for political settlements analysis because it appears that powerful groups disagree violently. But powerful groups disagree violently (in the metaphorical sense) in many countries, including for instance in the United States in recent years, and actual levels of violence are high in many developing countries, including in neighbouring Pakistan or India, even if not as high as in Afghanistan. It will be hard to agree on the level of violence at which we say a political settlement has disappeared. An easier question to ask is whether the key institutions, formal and informal, that are important for system reproduction, are reproducing. Even if reproduction requires external assistance, we need to understand the characteristics of the system reproduction and its implications for dynamics. Moreover, different types of external assistance can play a critical role in the system reproduction of many developing countries. This does not mean that all these settlements are dynamically sustainable, that is a different assessment, and we need to look at the direction of their evolution in the way I suggested earlier. From this perspective we could say, perhaps without too much controversy, that the political settlement in Afghanistan is only sustainable with a substantial and persistent international intervention. The challenge for progressive friends of Afghanistan is not to ask how we 'create' a political settlement there, but to ask what can be done to nudge its political settlement in ways that productive organizations are strengthened and the system remains sustainable with declining international military support.

I can now summarize what I see as the fundamental differences between our approaches. Kelsall essentially sees a political settlement as a 'planned order'. They are planned because they are based on a deliberately made set of agreements amongst an identifiable group of powerful organizations to set up institutions that they collectively agree are required to stop conflicts: these institutions are therefore likely to be robust and difficult-to-change. This implies that political settlements change only very occasionally and in discrete steps, and each change will require a new set of agreements. It follows that the analysis of political settlements should be limited to examining these big shifts in core institutions, leaving other institutional analysis to other methods.

My approach to political settlements is radically different. It sees a political settlement as an 'interactive order'. Political settlements are not based on agreements between the powerful or anyone else. The powerful are not a discrete set of organizations because power is usually based on networks and coalitions. Moreover, there are no enforcement agencies for policing agreements between groups, so while the 'powerful' can have plans and make agreements, like everyone else, the actual outcome at a systemic level is an interactive one that depends on the responses of all organizations to each other's plans and actions. In this conception, social orders also have rigidity; they usually 
change relatively slowly and their characteristics are stable enough in most cases to be an object of study, but they are not fixed by agreement.

In the 'interactive order' view, political settlements have an order in the same way that a market economy has an order. There was a time when some economists believed that a planned economy could impose an order by agreement (the plan), but we know that actual outcomes in planned economies depended on the responses of millions of decision-makers to the 'plan'. There was always a significant gap between plan and reality. What this means is that planned orders where powerful groups were apparently making the plans, were actually interactive orders in my sense because plans could not be fully implemented, even in one-party states. ${ }^{17}$ In the same way, when the configuration of power in a developing country appears to be highly skewed, it may look like a few powerful organizations are imposing an order on the rest of society. But even in these contexts, the story is much more complex, and a more sophisticated mapping of the configuration of power is required to understand differences in outcomes between these societies. ${ }^{18}$ Individuals and organizations have agency, but no group, even a group of the ostensibly powerful, can impose society-level institutions or policies unless these are aligned with the interests of and their enforcement is compatible with the holding power of many organizations affected by these institutions.

Organizations at all levels of society support or resist the implementation of institutions depending on their interests and their relative power vis-à-vis other organizations at that level. This interactive process brings about an alignment of power and rents more realistically, and without falling into traps of asserting non-credible agreements. It also means many apparently not-very-powerful organizations can capture rents if they are part of patron-client networks or other types of coalitions that give them localized power. The interactive-order approach also suggests that the political settlement is always incrementally evolving, but it can have occasional discontinuous step changes. In this adjustment process, institutions, organizations and configurations of power mutually adapt. Finally, in the interactive order approach, the political settlements framework is potentially relevant for the analysis of all institutions, because the operation of any institution is affected by the relative power of organizations at the appropriate level of analysis.

\section{Implications}

There are two further important implications of the differences between my analysis of a political settlement and that offered by Kelsall. First, if we fail to understand the complexity of the organizational interactions that result in a social order, we can mistakenly look for the pact or agreement that holds it all together. Political settlements are the outcome of agency in the sense of the complex interactions of the agency of many players. Defining a political settlement as an agreement or pact can give the

\footnotetext{
17 Michael Ellman, Socialist planning (Cambridge University Press, Cambridge, 2014), chapter one; Alec Nove, The Soviet economic system (Unwin Hyman, Boston MA, 1986), chapter three.

18 See for example my comparison of authoritarianism in Pakistan and South Korea in the 1960s in Mushtaq Husain Khan, The political economy of industrial policy in Pakistan 1947-1971, <http://eprints.soas.ac.uk/9867/>, Department of Economics Working Paper No. 98 (SOAS University of London, London, 1999); Khan, 'Rent-seeking as process'; Khan, Political settlements and the governance of growth-enhancing institutions.
} 
impression (even if unintended) that the pact or agreement is itself a policy variable that we can directly help to achieve. Policy-makers may be tempted to rush off trying to negotiate 'conflict-ending agreements' or even 'inclusive' variants of these, even if this was not intended by the researcher. This misunderstands the nature of the 'agency' that is at issue here. Thousands of organizations and sub-organizations (if not more) are typically involved in a society in rent-seeking decisions to deploy their holding power and capabilities to support, block or alter institutions. That is indeed agency, but not agency that is a policy variable at the system level. Political settlements are the outcomes of these complex organizational agency interactions.

Political settlements are therefore like weather systems. Just as understanding weather systems and how they are evolving can be useful for telling us the likely effects of planting crops on a particular day, understanding the characteristics of a political settlement can tell us how particular institutions or policies may be distorted or blocked. For me, this is the most valuable application of the political settlements framework, to analyse and identify the implications of incremental changes in different directions. But the agreement to construct a political settlement itself is not a meaningful policy variable, just as (with our current state of knowledge) we cannot order all the complex planetary and inter-planetary factors that go into making a perfectly balmy summer's day. This does not mean that agency does not have an effect on the structure of the political settlement, it just means that the effects are not determinate enough in a policyrelevant sense. In just the same way, reducing our emission of greenhouses gases is very likely to have an effect on global warming but the complexity of the relationships makes it difficult to say with any precision whether the effect will be significant or not. In the same way that we can be risk averse and take steps to reduce emissions, we can support interventions that are more likely to nudge the evolution of political settlements in sustainable directions once we understand its characteristics. But this type of analysis is in its infancy and we do not know enough about how practical interventions can nudge political settlements in determinate directions.

A second related error in the opposite direction is to think that a political settlement is in some sense a carefully constructed agreement to prevent violence and protecting its critical institutions is somehow important to preserve the peace. This can lead to the equally mistaken strategy of always wanting to work in alignment with elite interests (because we assume these elites have carefully put together institutions that are important for preventing violence). This too is mistaken. Many long-lasting social orders can not only be quite exclusionary and generate low growth, they can also involve much repression and violence. There is no reason to believe that these arrangements should be protected or respected in order to prevent conflict. We may be quite justified in wanting to change the political settlement and go against the interests of powerful groups, but not in the simplistic sense of the first mistake. There is no meaningful sense in which we can 'renegotiate' some more inclusive 'agreement'. Rather, we need to have a much better understanding of the ways in which particular political settlements are evolving so that we can advise or help dissidents to incrementally chip away at this distribution of power with implementable policies or institutions that can help to nudge changes in particular directions. This is after all how political settlements incrementally change in any case, as a result of agency interventions at a micro level. This is a challenging research objective, and we are at an early stage here, but it is important to understand that the political settlement is the structure we want to change because it has implications for institutions and therefore 
for economic and political outcomes. It is neither a policy variable that can be directly changed with an appropriate agreement, nor is it a fundamental conflict-prevention agreement that is always essential to preserve. 